\title{
PENGARUH MOTIVASI DAN KEPUASAN KERJA TERHADAP KINERJA KARYAWAN DI PERUSAHAAN DAZZEL YOGYAKARTA
}

\author{
Tri Finta Syandi Syah Endra ${ }^{1}$ \\ Universitas Sarjanawiyata Tamansiswa, Ekonomi, Manajemen \\ 1) trifintas@gmail.com
}

\begin{abstract}
ABSTRAK
Penelitian ini bertujuan untuk mengetahui apakah motivasi dan kepuasan kerja berpengaruh signifikan terhadap kinerja karyawan pada Perusahaan Dazzle Yogyakarata. Penelitian ini menggunakan metode regresi linier berganda dengan pengolahan data primer menggunakan SPSS (Statistical Product and Service Solutions) $V$. 25. Analisis data yang digunakan adalah analisis data deskriptif dan data kuantitatif. Pengumpulan data dilakukan melalui observasi dan angket. Hasil penelitian ini menunjukkan bahwa motivasi dan kepuasan karyawan berpengaruh positif dan signifikan terhadap kinerja karyawan pada uji ANOVA Perusahaan Dazzle Yogyakarta. Penelitian ini juga menghasilkan temuan bahwa secara simultan atau bersama-sama motivasi dan kepuasan kerja berpengaruh positif dan signifikan pada Dazzle Company Yogyakarta.
\end{abstract}

Kata kunci: Motivasi, tujuan, dan kinerja.

\section{PENDAHULUAN}

Dalam perkembangan jaman modern saat ini, berbagai macam aspek keunggulan dibutuhkan oleh setiap organisasi dalam rangka mencapai tujuannya. Sebuah organisaasi atau perusahaan membutuhkan adanya potensi dan kekuatan internal yang kuat untuk rangka menghadapi berbagai tantangan dan perubahan. Organisasi yang dapat mengatasi masalah dengan strategi yang tepat dan sesuai kondisi akan lebih mudah maju dan berkembang. Salah satu faktor penting yang diperlukan perusahaan untuk mencapai tujuan organisasi adalah faktor sumber daya manusia.

Eksistensi dan kompetensi perusahaan atau organisasi dipengaruhi oleh manusia yang menjadi unsur penting dalam organisasi tersebut. Ini berarti bahwa eksistensi dan kompetensi organisasi dapat diraih dengan aktivitas manusia di dalamnya. Oleh karena itu, eksis atau kompetitif tidaknya sebuah organisasi, sangat ditentukan oleh manusia. Hal ini menjadi krusial, khususnya dalam menghadapi arus perubahan zaman, lingkungan, atau iklim bisnis sekarang dan masa mendatang.

Setiap organisasi atau perusahaan diharapkan mampu mengelola dan mengatur aspek sumber daya manusia yang dimilikinya dengan sebaik mungkin. Karena dengan terkelolanya factor sentral ini melalui manajemen sumber daya manusia yang baik, tujuan dan cita-cita perusahaan akan dapat tercapai. Manajemen sumber daya manusia menurut Handoko (2011:3) ialah kegiatan untuk meraih baik itu tujuan personal maupun organisasi dengan cara penarikan, seleksi, pengembangan, pemeliharaan, dan penggunaan sumber daya manusia. Peningkatan kualitas manusiapun dapat dilakukan dengan manajemen sumber daya manusia, yakni melalui upaya memperbaiki sumber daya manusia, meningkatkan kinerja dan daya hasil organisasi. Sebagai hasilnya, karyawan yang memiliki disiplin dan kinerja yang tinggi akan terwujud.

Dua faktor penting yang mempengaruhi kinerja karyawan adalah motivasi dan kepuasan kerja. Motivasi adalah sebuah faktor yang lebih mengarah pada perilaku dalam organisasi. Motivasi berasal dari kata dalam bahasa inggris, yakni motive yang berarti 
keadaan dalam diri seseorang yang menimbulkan kekuatan, menggerakkan, mendorong, dan mengarahkan (Handoko, 2002:252). Motivasi merupakan keadaan dalam diri individu yang mendorong keinginannya untuk melakukan berbagai kegiatan guna mencapai tujuan yang ingin digapai. Dengan demikian, motivasi merupakan faktor yang ada dalam diri manusia yang menggerakkan perilaku untuk memenuhi tujuan tertentu. Dalam praktiknya, seorang karyawan yang mempunyai motivasi kerja yang tinggi, cenderung memiliki kinerja yang baik dan tinggi pula. Oleh kerena itulah, motivasi merupakan faktor yang sangat substansial dalam upaya peningkatan kinerja karyawan.

Disamping faktor motivasi kerja, kinerja karyawan juga ditentukan oleh kepuasan kerja. Menurut As'ad (2002:133) kepuasan kerja adalah kondisi emosional menggembirakan pada karyawan dalam melihat pekerjaan yang mereka lakukan. Kepuasan kerja merefleksikan perasaan seseorang terhadap pekerjaannya. Hal ini akan terlihat dari sikap mereka terhadap pekerjaan dan segala sesuatu di lingkungan kerjanya. Menurut Handoko (2000:193) menciptakan kepuasan kerja karyawan adalah kewajiban setiap pemimpin. Hal ini karena kepuasan kerja adalah salah satu faktor yang dapat mendorong dan mempengaruhi semangat kerja karyawan sehingga mereka dapat bekerja dengan baik dan berprestasi. Agar karyawan merasa terpuaskan, seorang manajer perlu memberikan suasana kerja yang mendukung dan menyenangkan serta jaminan keselamatan kerja yang memadai.

Dazzel merupakan Usaha Mikro Kecil dan Menengah (UMKM) yang bergerak di sektor penjualan berbagai aksesoris smartphone yang beroperasi di Jl. Affandi No.8, Karang Gayam Caturtunggal Kec. Depok, Kabupaten Sleman, Daerah Istimewa Yogyakarta. Berdasarkan pengamatan yang dilakukan oleh peneliti pada motivasi kerja karyawan Dazzel, nampak bahwa pegawai kurang bersemangat dalam bekerja dan kurang disiplin. Hal ini dapat ditunjukkan dengan banyaknya karyawan yang datang ke kantor terlambat. Selain itu, masih ada karyawan yang keluar masuk pada waktu jam kerjanya. Peneliti juga melakukan pengamatan pada kepuasan kerja karyawan. Nampak bahwa masih ada karyawan yang memiliki sikap kurang percaya diri dalam menyelesaikan tugasnya. Kurangnya motivasi dan kepuasan kerja dalam berkerja membuat kinerja karyawan menjadi tidak maksimal unuk mencapai tujuan suatu organisasi tersebut. Dalam hal ini sangat berpengaruh terhadap kinerja karyawan tersebut. Oleh sebab itulah, penelitian ini bertujuan untuk mengetahui apakah motivasi dan kepuasan kerja berpengaruh signifikan terhadap kinerja karyawan Perusahaan Dazzle Yogyakarata.

\section{LANDASAN TEORI}

\section{Kinerja Karyawan}

Kinerja menurut (Gomes, 2003) merupakan catatan dari hasil akhir yang dikerjakan atau diproduksi pada fungsi pekerjaan atau kegiatan tertentu selama periode tertentu. Kinerja karyawan ialah hasil yang diraih oleh individu dalam suatu organisasi baik secara kuatitatif atau kualitatif, yang sesuai kewenangan dan tanggung jawabnya untuk mencapai tujuan organisasi (Moeheriono, 2012).

Berdasarkan pengertian-pengertian di atas dapat disimpulkan bahwa kinerja adalah suatu hasil kerja yang dicapai oleh karyawan atas apa yang telah dikerjakannya, sesuai dengan standar dan kriteria yang ditetapkan oleh perusahaan. Kinerja karyawan memiliki

beberapa indikator penting seperti kualitas kerja, kuantitas, pelaksaan tugas, dan tanggung jawab. Berdasarkan penjelasan di atas dapat diketahui juga bahwa kinerja 
adalah pencapaian hasil kerja seseorang atau keseluruhan dalam waktu tertentu di dalam melaksanakan tugas dan tanggung jawab di suatu perusahaan atau organisasi.

\section{Motivasi}

Agar tujuan organisasi tercapai, kinerja karyawan haruslah dikembangkan. Kinerja karyawan yang baik dipengaruhi oleh motivasi kerja yang tinggi, sehingga dalam hal ini motivasi keja sangat penting dan dibutuhkan. Pegawai dapat bekerja dengan kinerja tinggi karena adanya dorongan motivasi kerja dalam diri mereka.

Motivasi kerja karyawan memegang peranan penting dalam keberhasilan organisasi karena motivasi dapat mempengaruhi tingkat produktivitas dan kualitas kerja karyawan pada perusahaan dan organisasi. Yuwono dkk. (2005) mendefinisikan motivasi sebagai suatu proses pengarahan, menjaga atau memelihara dan membangkitkan perilaku manusia agar terarah pada tujuan tertentu. Motivasi adalah suatu indikator penting seorang karyawan agar lebih puas menjalankan aktivitasnya. Motivasi kerja dapat dijadikan pendorong dalam diri manusia dan dapat mengarahkan perilaku untuk melaksanakan tugas dan tanggung jawab (Panggalih \& Zulaicha, 2012).

Menurut Elida Prayitno (1989:10) motivasi memiliki dua tipe yakni motivasi intrinsik dan motivasi ekstrinsik. Motivasi intrinsik adalah dorongan atau kehendak yang kuat yang berasal dari dalam diri seseorang (Gunarsa, 2008:50). Semakin kuat motivasi intrinsik seorang individu, maka semakin besar kemungkinan dirinya menunjukkan perilaku yang kuat untuk mencapai tujuan. Dinamakan sebagai motivasi esktrinsik karena tujuan utama individu melakukan kegiatan adalah untuk mencapai tujuan yang terletak di luar aktivitas pekerjaan itu. Gunarsa (2008:50) menyatakan bahwa motivasi ekstrinsik adalah segala sesuatu yang didapat dengan pengamatan sendiri, saran, anjuran, atau dorongan dari orang lain.

Motivasi kerja seseorang sangat bergantung pada faktor yang mempengaruhinya. Menurut Melayu S.P Hasibuan (2008:103) setiap manusia atau karyawan mengharapkan kompensasi dari prestasi yang diraih, serta ingin memperoleh pujian dan perlakuan yang baik dari atasannya.

\section{Kepuasan Kerja}

Kepuasan kerja merupakan pendorong hasil karyawan maupun organisasi karena kepuasan kerja merupakan hasil dari persepsi karyawan mengenai seberapak baik pekerjaannya memberikan hal yang dinilai penting. Kepuasan kerja adalah keadaan emosi positif maupun emosi negatif yang berasal dari penelitian terhadap pekerjaan atau pengalaman kerja karyawan.

Kepuasaan kerja adalah sikap yang positif dari tenaga kerja meliputi perasaan dan tingkah laku terhadap pekerjaannya melalui penilaian salah satu pekerjaan sebagai rasa menghargai dalam mencapai nilai-nilai yang penting dari pekerjaan (Afandi, 2018:74).

Menurut (Nuraini,2013) ada beberapa faktor yang mempengaruhi kepuasan kerja antara lain:

a. Upah yang cukup

Memenuhi kebutuhan merupakan keinginan setiap karyawan, sehingga upah yang cukup untuk memenuhi kebutuhan itu sangatlah penting.

b. Perlakuan yang adil

Setiap karyawan ingin diperlakukan secara adil dalam berbagai hal, tidak hanya dalam hal upah untuk menciptakan persepsi yang sama antara atasan dan bawahan mengenai makna yang sesungguhnya. 
c. Ketenangan bekerja

Setiap karyawan menginginkan ketenangan. Hal ini menyangkut bukan saja pekerjaannya tetapi juga terakit kesejahteraan keluarganya.

d. Perasaan diakui

Setiap karyawan ingin memiliki perasaan diakui sebagai karyawan yang berharga dan sebagai anggota kelompok yang dihormati di dalam organisasi.

e. Penghargaan hasil kerja

Karyawan menginginkan agar hasil karyawan dihargai, hal ini bertujuan agar karyawan merasa senang dalam berkerja dan akan selalu brkerja dengan giat.

f. Penyalur perasan

Perasaan yang menghinggapi karyawan bisa menghambat gairah karyawan, hal ini dapat diatasi melaui komunikasi dua arah secara timbal balik.

\section{METODE PENELITIAN}

Jenis penelitian yang digunakan dalam penelitian ini adalah penelitian kuantitatif dengan pendekatakan deskriptif. Metode penelitian kuantitatif merupakan salah satu jenis penelitian yang spesifiknya adalah sistematis, terencana dan terstruktur dengan jelas sejak awal hingga pembuatan desain penelitiannya (Sugiyono, 2013). Metode penelitian kuantitatif dapat diartikan sebagai metode penelitian berlandaskan pada filsafat positivisme, yang digunakan untuk meneliti populasi atau sampel tertentu. Sedangkan teknik pengambilan sampel pada umumnya dilakukan secara random, pengumpulan data menggunakan instrumen penelitian, analisis data bersifat kuantitatif atau statistik dengan tujuan untuk menguji hipotesis yang diterapkan (Sugiyono, 2013).

Variabel adalah suatu atribut sifat atau nilai dari orang, atau kegiatan yang mempunyai variasi tertentu yang ditetapkan oleh penelitian untuk dipelajari dan kemudian ditarik kesimpulannya Sugiyono (2013).

\section{a. Variabel Dependen}

Varibel dependen sering disebut variabel outpun, kriteria, konsukuen adalah varibel yang dipengaruhi atau yang menjadi akibat karena adanya variabel bebas (Sugiyono, 2013:63). Variabel dependen peneliatian ini adalah kinerja karyawan. Kinerja karyawan adalah merupakan hasil kerja dan perilaku kerja yang telah dicapai dalam menyelesaikan tugas-tugas dan tanggung jawab yang diberikan dalam suatu periode tertentu (Kasmir 2016:138).

\section{b. Variabel Independen}

Variabel independen sering disebut sebagai varibel stimuls, predictor, antecedent adalah yang mempengaruhi atau yang menjadi sebab perubahan atau timbulnya varibel (terikat) (Sugiyono 2013:63).

1) Motivasi (X1)

Menurut Hasibuan dalam (Saputra \& Parwoto, 2020), motivasi kerja merupakan bekal sebagai penggerak yang menimbulkan semangat kerja seseorang, sehingga ia berkenan untuk bekerja dengan keras dan bersemangat dalam upaya mencapai hasil yang optimal.

2) Kepuasan Karyawan (X2)

Dalam sebuah pekerjaan, kepuasan kerja dapat dinikmati ketika berada di dalam dan di luar pekerjaan tersebut. Bahkan tidak sedikit kepuasan kerja juga dapat dinikmati 
baik didalam maupun diluar suatu pekerjaan menurut Putra \& Frianto dalam Saputra \& Parwoto (2020).

\section{HASIL DAN PEMBAHASAN}

\section{Hasil Penelitian}

Dazzle Celuler Accsesories (Dazzle AC) merupakan sebuah retail company yang sedang berkembang. Perusahaan ini didirikan pada tanggal 7 juli 2002 oleh Bapak Yudo Satrio dan Ibu Diana Riasari. Perusahaan in bergerak di bidang handphone accessories yang terletak di Jalan Kaliurang KM 5,6 Yogyakarta. Menurut beliau, pangsa pasar bisnis dibidang accessories handphone sangat bagus, apalagi seperti kota Yogyakarta.

Pada awalnya Dazzle CA tidak lebih seperti toko-toko lainnya yang sebelumnya terletak di Jalan Kaliurang KM 4,5 Yogyakarta dengan luas bangunan 3,5x4,5 meter. Toko ini kemudian maju dan berkembang sehingga pada tanggal 1 Januari 2003 toko melakukan perluasan tempat dengan menambah bangunan yang ada di sebelah toko yang mempunyai ukuran 7x4,5 meter. Sumber daya manusia, manajemen, strategi penjualan, dan strategi pengatasan permasalahan yang baik dan berkualitas membuat Dazzle CA semakin maju dan berkembang. Pada tanggal 25 Agustus 2003, Dazzle CA berpindah tempat ke Jalan Kaliurang KM 5,6 Yogyakarta. Tempat baru ini mempunyai luas bangunan $14,5 \times 9$ meter.

Melihat kemajuan dan perkembangan perusahaan, Yudo Sationo dibantu dengan istrinya Diana Riasari mulai merencanakan membuat sebuah struktur perusahaan yang baik, lengkap dengan prosedur-prosedur yang diperlukan dalam suatu kegiatan dan job description masing-masing bagian. Baliau percaya bahwa perusahaan tidak maju jika tidak didukung oleh suatu jaringan prosedur yang dibuat menurut pola yang terpadu untuk melaksanakan kegiatan pokok perusahaan yang baik. Tidak heran jika perusahaan ini kemudian dapat berkembang dengan cepat.

Adapun Visi Dazzle CA adalah "Menjadikan Dazzle CA sebagai pusat penjualan accesoris handphone terbesar, terlengkap, dengan produk layanan berkualitas. Visi itu diwujudkan dalam misinya yakni "Niat baik dan kerja keras". Dilengkapi dengan semboyan baik secara internal maupun eksternal Dazzle CA. Semboyan untuk internal mereka adalah "Tetap semangat". Sedangkan semboyan untuk eksternal adalah "Make your phone different."

\section{Karakteristik Responden Penelitian}

Responden dalam penlitian ini adalah seluruh pegawai dari Dazzle CA Yogyakarta yang berjumlah 37 responden. Dari kuesioner yang disebarkan respondend dihasilkan beberapa gambaran karakteristik responden sebagai berikut:

Tabel 1 : Karakterisik Responden Berdasarkan Jenis Kelamin

\begin{tabular}{cccc}
\hline No & Keterangan & Jumlah & Presentase \\
\hline 1 & Jumlah Laki-Laki & 11 & $32 \%$ \\
2 & Jumlah Perempuan: & 23 & $68 \%$ \\
\hline & Total & 34 & $100 \%$ \\
\hline
\end{tabular}

Sumber : Data Primer diolah, 2021

Berdasarkan table 1 dapat diketahui bahwa dari jumlah responden sebanyak 34 orang terbagi berjenis kelamin laki-laki sebanyak 11 orang atau 32 persen, sedangkan 
responden perempuan sebanyak 23 orang atau 68 persen. Hal ini menunjukan bahwa mayoritas konsumen yang menjadi responden dalam penelitian adalah perempuan.

Tabel 2 : Karakteristik Responden Berdasarkan Pendidikan

\begin{tabular}{cccc}
\hline No & Pendidikan Terahir & Jumlah & Persentase \\
\hline 1 & SMA & 15 & $44 \%$ \\
2 & SMK & 15 & $44 \%$ \\
3 & S1 & 4 & $12 \%$ \\
\hline & Total & 34 & $100 \%$ \\
\hline
\end{tabular}

Sumber: Data Primer diolah, 2021

Berdasarkan table 2 di atas, menunjukkan bahwa dari total 34 responden, maka 15 orang berpendidikan terakhir SMA dengan persentase 44 persen, 15 orang berpendikan SMK dengan total 44 persen, sedangkan yang berpendidikan S1 berjumlah 4 dengan 12 persen.

Table 3 : Karakteristik Responden Berdasarkan Usia

\begin{tabular}{cccc}
\hline No & Rentang Usia & Jumlah & Persentase \\
\hline 1 & $<15-25$ & 28 & $82 \%$ \\
2 & $<25-35$ & 6 & $18 \%$ \\
\hline & Total & 34 & $100 \%$ \\
\hline
\end{tabular}

Sumber Data Primer diolah 2021

Berdasarkan tabel 3 menunjukan bahwa usia karyawan di Perusahaan Dazzle kurang dari 30 tahun, yaitu 28 responden dengan persentase 82 persen, 25 sampai dengan 31 tahun berjumlah 6 responden dengan persentase 18 persen.

Tabel 4 : Karakteristik Responden Berdasarkan Lama Kerja

\begin{tabular}{cccc}
\hline No & Lama Kerja & Jumlah & Persentase \\
\hline 1 & $<1$ Bulan-11 Bulan & 25 & $74 \%$ \\
2 & $<1-11$ Tahun & 9 & $26 \%$ \\
\hline & Total & 34 & $100 \%$ \\
\hline
\end{tabular}

Sumber Data Primer diolah, 2021

Berdasarkan table 4 di atas, dapat ditunjukkan bahwa lama berkerja responden di Perusahaan Dazzle CA paling besar yaitu kurang dari 1 tahun yaitu sebesar 25 responden dengan persentase 74 persen, 1 sampai 11 tahun sebanyak 9 responden dengan persentase 26 persen.

\section{Hasil Deskriptif Statistik}

Analisis data merupakan langkah selanjutnya yang dilakukan setalah data terkumpul, yakni rangkaian kegiatan berupa mengumpulkan data, mengolah data, menganalisis data, dan melakukan perhitungan untuk menguji hipotesis yang diajukan (Ghozali, 2016). 
Tabel 5 : Hasil Statistik Deskriptif Descriptive Statistics

\begin{tabular}{|c|c|c|c|c|c|}
\hline & $\mathbf{N}$ & Minimum & Maximum & Mean & Std. Deviation \\
\hline Total_X1 & 34 & 16 & 23 & 19.32 & 1.838 \\
\hline Total_X2 & 34 & 13 & 25 & 18.94 & 2.933 \\
\hline Total_Y & 34 & 15 & 25 & 18.85 & 2.271 \\
\hline Valid $\mathrm{N}$ (listwise) & 34 & & & & \\
\hline
\end{tabular}

Sumber: Data diolah (2021)

Dari data diatas dapat diketahui bahwa dalam penelitian ini terdapat 34 data yang diuji. Untuk variabel motivasi dari data tersebut memiliki nilai minimum yaitu 16 dan nilai maksimum 23. Untuk rata rata dari variabel motivasi yaitu 19,32 dan standar deviasi yaitu 1,838. Kepuasan kerja memiliki nilai minimum 13 dan nilai maksimum 23. Untuk rata-rata variabel kepuasan kerja yaitu 18,94 dan standar deviasinya sebesar 2,993. Yang terkhir untuk variabel kinerja karyawan memiliki nilai minimum 15 dan nilai maksimumnya yaitu 25. Rata-rata dari variabel ini yaitu 18.85 dan standar deviasi 2,271.

\section{Hasil Uji Kualitas Data}

\section{a. Hasil Uji Validitas}

Uji validitas dihitung dengan membandingkan nilai $r$ hitung (correlated item total correlation) dengan nilai $r$ tabel. Jika $r$ hitung $>r$ tabel dan nilai positif maka pertanyaan yang diajukan dinyatakan valid (Ghozali, 2016). Skor masing-masih item haruslah berkolerasi secara signifikan dengan skor totalnya. Suatu instrumen penelitian dikatakan valid bila koefisien kolerasi produk moment $>\mathrm{r}$ tabel $(0,01 ; 30-2) \mathrm{n}=34-2=32$ dengan alpha 0.05. dapat dihasilkan $r$ tabel 0,2869. Sebagai berikut penyajian uji validitas pada variabelnya:

Tabel 6 : Hasil Uji Validitas

\begin{tabular}{lllll}
\hline Variabel & Item & r hitung & r tabel & keterangan \\
\hline Motivasi & X1.1 & 0.511 & 0,2869 & Valid \\
& X1.2 & 0.323 & 0,2869 & Valid \\
& X1.3 & 0.482 & 0,2869 & Valid \\
& X1.4 & 0.787 & 0,2869 & Valid \\
& X1.5 & 0.732 & 0,2869 & Valid \\
\hline Kepuasan kerja & X2.1 & 0.839 & 0,2869 & Valid \\
& X2.2 & 0.779 & 0,2869 & Valid \\
& X2.3 & 0.926 & 0,2869 & Valid \\
& X2.4 & 0.856 & 0,2869 & Valid \\
& X2.5 & 0.823 & 0,2869 & Valid \\
\hline Kinerja karyawan & Y1 & 0.780 & 0,2869 & Valid \\
& Y2 & 0.766 & 0,2869 & Valid \\
& Y3 & 0.762 & 0,2869 & Valid \\
& Y4 & 0.645 & 0,2869 & Valid \\
& Y5 & 0.805 & 0,2869 & Valid
\end{tabular}

Sumber: data diolah, 2021

Pada tabel 6 di atas, dapat diketahui bahwasannya di setiap indikator variabel adalah valid, yaitu $r$ hitung lebih besar dari $r$ tabel ( $r$ hitung $>$ dari $r$ tabel) dimana $r$ tabelnya 
sebesar 0.278 maka dari itu dapat disimpulkan bahwasannya semua indikator pertanyaanya pada kuisioner untuk mengukur data penelitian dapat dikatakan valid.

\section{b. Hasil Uji Reabilitas}

Reabilitas adalah alat untuk mengukur kuesioner yang merupakan bagian indikator dari variabel. Suatu kuesioner dikatakan reliabel atau handal apabila jawaban seseorang terhadap pertanyaan adalah konsisten atau stabil dari waktu ke waktu (Ghozali, 2016). Untuk mengukur reabilitas maka dilakukan dengan uji statistik Cronbach Alpa (a), dimana variabel dikatakan reliabel jika memberikan nilai a $>0,60$. Hasil dapat dilihat pada tabel berikut ini:

Tabel 7 : Hasil Uji Reabilitas

\begin{tabular}{lccc}
\hline \multicolumn{1}{c}{ Uji Reliabilitas } & Item & Cronbach alpha & Keterangan \\
\hline Motivasi & X1 & 0,672 & Reliabel \\
kepuasan kerja & X2 & 0.898 & Reliabel \\
kinerja karyawan & $\mathrm{Y}$ & 0.807 & Reliabel \\
\hline
\end{tabular}

Sumber: data diolah,2021

Pada tabel di atas 7 dapat diketahui bahwa nilai koefisien reliabilitas untuk variabel motivasi (X1) dan kepuasan (X2) masing-masing lebih besar dari nilai Rule of Thumb sebesar 0,600 sehingga semua pernyataan untuk setiap variabel tersebut dinyatakan reliabel dan dapat digunakan sebagai alat pengumpulan data.

\section{Hasil Uji Hipotesis}

Hipotesis merupakan jawaban sementara atas permasalahan yang dirumuskan. Oleh karena itu, jawaban sementara ini harus diuji dengan menggunakan analisis regresi berganda yaitu uji t (Ghozali, 2016).

a. Hasil Uji t

Uji t dilakukan untuk menguji apakah variabel motivasi (X1) dan variabel kepuasan kerja (X2) secera parsial atau masing-masing memiliki pengaruh yang signifikan terhadap kinerja karyawan (Y) pada perusaan dazzle Yogyakarta.

Tabel 8 : Hasil Uji t

Coefficients $^{\mathbf{a}}$

\begin{tabular}{|c|c|c|c|c|c|c|}
\hline \multirow{2}{*}{\multicolumn{2}{|c|}{ Model }} & \multicolumn{2}{|c|}{ Unstandardized Coefficients } & \multicolumn{3}{|l|}{$\begin{array}{l}\text { Standardized } \\
\text { Coefficients }\end{array}$} \\
\hline & & B & Std. Error & Beta & $\mathbf{t}$ & Sig. \\
\hline 1 & (Constant) & 9.523 & 3.678 & & 2.589 & 0.015 \\
\hline & Total_X1 & 0.129 & 0.281 & 0.104 & 1.759 & 0.040 \\
\hline & Total_X2 & 0.361 & 0.176 & 0.466 & 2.048 & 0.049 \\
\hline
\end{tabular}

Sumber data diolah 2021

Hipotesis pertama dari penelitian ini adalah H1: motivasi berpengaruh positif terhadap kinerja karyawan. Penelitian ini menguji 34 data dan signifikansinya adalah 0,05 . Variabel motivasi memiliki nilai thitung $>\mathrm{t}$ tabel yaitu dengan $1.759>1.69$, berarti hal ini ada pengaruh positif variabel motivasi terhadap kinerja karyawan. Sedangkan untuk signifikansi motivasi memiliki nilai sebesar 0,040 berarti lebih kecil dari 0,05 yang berarti variabel motivasi berpengaruh signifikan terhadap kepuasan karyawan.

Sementara itu, H2 : kepuasan kerja berpengaruh positif terhadap kinerja karyawan. Penelitian ini menguji 50 data. Nilai signifikannya adalah 0,05 . Untuk variabel kepuasan 
kerja memiliki t hitung $>\mathrm{t}$ tabel yaitu $2.048>1.69$. Ini berarti bahwa terdapat pengaruh positif kepuasan kerja terhadap kinerja karyawan. Untuk nilai sig. 0.49 berarti lebih kecil dari 0,05. Hal ini dapat dilihat bahwa ada pengaruh signifikansi kepuasan kerja terhadap kinerja karyawan.

b. Hasil uji F

Untuk dapat mengetahui nilai uji $\mathrm{F}$ didapat dari hasil output software statistik dengan nilai $f$ dan nilai signifikansi, yang mana nilai f dibandingkan dengan nilai $f$ tabel dengan cara:

$$
\begin{aligned}
& \mathrm{F} \text { tabel }=(\mathrm{df} 1 ; \mathrm{df} 2) \\
& \mathrm{F} \text { tabel }=\{(\mathrm{k}-1) ;(\mathrm{n}-\mathrm{k})\} \\
& \mathrm{F} \text { tabel }=\{(3-1) ;(34-2)\} \\
& \mathrm{F} \text { tabel }=\{(2)-(32)\}
\end{aligned}
$$

Keterangan :

df1 $=$ degree of freedom untuk pembilangan $(\mathrm{N} 1)$

df2 $=$ degree offfreedom untuk pembilangan (N2)

$\mathrm{k}=$ jumlah variable independen dan dependen

$\mathrm{n}=$ jumlah sampel

Tabel 9 : Hasil Uji F

ANOVA $^{\mathrm{a}}$

\begin{tabular}{llrrrrr}
\hline & Model & Sum of Squares & df & Mean Square & F & Sig. \\
\hline 1 & Regression & 51.285 & 2 & 25.643 & 6.681 & $0.004^{\mathrm{b}}$ \\
Residual & 118.980 & 31 & 3.838 & & \\
& Total & 170.265 & 33 & & &
\end{tabular}

Sumber: Data diolah, 2021

Ha : Berdasarkan nilai f hitung > f tabel maka variable bebas secara simultan berpengaruh terhadap vaiabel terikat

Ho : jika nilai $\mathrm{f}$ hitung < $\mathrm{f}$ tabel maka variabel bebas secara simultan berpengaruh signifikan terhadap variabel terikat.

Hipotesis ketiga dalam penelitian ini adalah $\mathrm{H} 3$ : adanya pengaruh motivasi dan kepuasan kerja terhadap kinerja karyawan. Dapat dilihat pada tabel 4.9 bahwa f hitung ( $6.681)>\mathrm{f}$ tabel (2.51) yang berarti variabel motivasi dan kepuasan kerja berpengaruh terhadap variabel kinerja karyawan. Selain itu, berdasarkan nilai signifikan bahwa nilai sig. $(0.004)<(0.05)$, maka variabel motivasi dan kepuasan karyawan berpengaruh signifikan terhadap variabel kinerja karyawan. Jadi, hipotesis 3 dapat diterima yaitu adanya pengaruh motivasi dan kepuasan kerja karyawan secara simultam terhadap kinerja karyawan.

\section{PEMBAHASAN}

Dalam penelitian ini pengaruh variable independent dan variable dependen yang digambarkan dengan model paradigm penelitian. Berikut merupakan model paradigm pada penelitian ini mengenai motvasi dan kepuasan kerja terhadap kinerja karyawan pada perusahaan Dazzle Yogyakarta. 


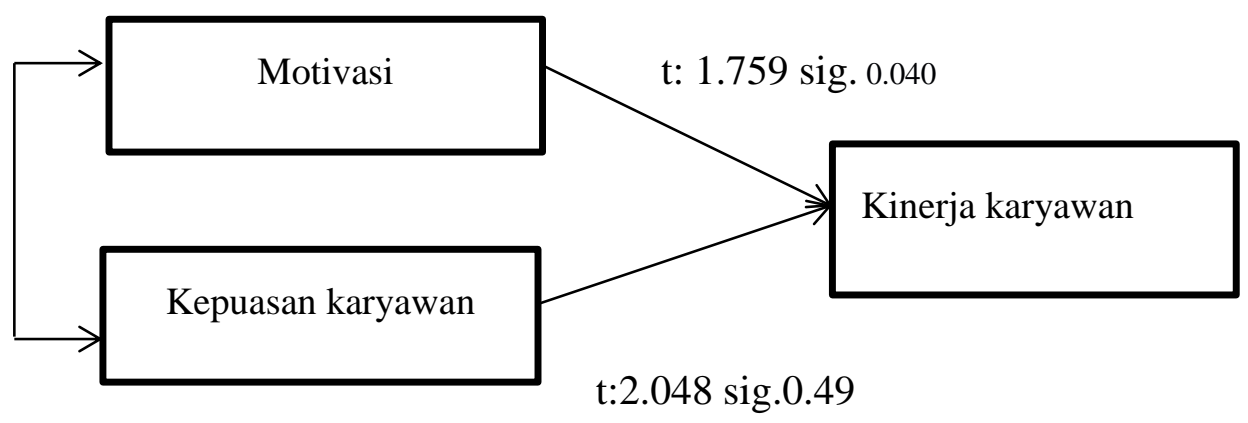

\section{Gambar 1. Hasil Uji Regresi Linier Pada Kerangka Pemikiran}

Sumber data diolah, 2021

Dari gambar diatas dapat diketahui bahwa terdapat pengaruh positif dan signifikan motivasi terhadap kinerja karyawan. Untuk kepuasan kerja juga terdapat pengaruh positif dan signifikan terhadap kinerja karyawan. Maka dapat disimpulkan bahwa:

\section{Pengaruh Motivasi terhadap Kinerja Karyawan}

Hasil penelitian menunjukkan bahwa terdapat pengaruh positif dan signifikan variabel motivasi terhadap kinerja karyawan di Perusahaan Dazzle Yogyakarta. Hasil penelitian ini sejalan dengan penelitian (Prabowo et al,2018) dan (Dotulong \& Assagaf, 2015). Hasil penelitian-penelitian itu menunjukkan bahwa terdapat pengaruh positif antara variabel motivasi terhadap kinerja karyawan. Dengan demikian maka apabila sebuah perusahaan dapat meningkatkan motivasi diri karyawan, maka dapat meningkatkan kinerja karyawan.

\section{Pengaruh Kepuasan Kerja terhadap Kinerja Karyawan}

Dari hasil penelitian membuktikan bahwa pengaruh kepuasan kerja terhadap kinerja karyawan adalah signifikan. Artinya hasil pengujian membuktikan bahwa kepuasan kerja terhadap kinerja karyawan pada perusahaan Dazzle Yogyakarta terbukti. Hasil penelitian ini dapat dilihat bahwa dengan kepuasan kerja yang baik dari perusahaan akan meningkatkan kinerja karyawan. Hasil ini sesuai dengan hasil kesimpulan yang dibuat (Sutama dan Stiven, 2014) yang menyatakan bahwa kepuasan kerja yang tinggi akan memberikan pengaruh yang baik juga pada kinerja karyawan.

\section{PENUTUP}

\section{Kesimpulan}

Berdasarkan hasil uji dapat disimpulkan bahwa:

1) Motivasi berpengaruh positif dan signifikan terhadap kinerja karyawan di Perusahaan Dazzel Yogyakarta. Hal ini dapat dilihat dari nilai t hitung yaitu sebesar 1.759 lebih besar dari t tabel 1.69 berarti terdapat pengaruh yang positif. Kemudian nilai sig dari hasil uji hipotesis yaitu 0,040 lebih kecil dari 0,05 berarti terdapat signifikasi. Jadi dapat disimpulkan bahwa kinerja karyawan berpengaruh positif dan signifikan terhadap motivasi kerja secara parsial di perusahaan Dazzel Yogyakarta.

2) Kepuasan kerja berpengaruh positif dan signifikan terhadap kinerja karyawan di Perusahaan Dazzel Yogyakarta. Hal ini dapat dilihat dari hasil uji bahwa nilai t 
hitung 2.048 lebih besar dari t tabel 1.69 dan nilai sig 0.49 berarti lebih kecil dari 0,05. Dengan demikian berarti bahwa terdapat pengaruh positif dan signifikan kepuasan kerja terhadap kinerja karyawan secara parsial di Perusahaan Dazzel Yogyakarta.

\section{Saran}

Berdasarkan hasil penelitian yang telah dilakukan, maka dapat dikemukakan beberapa saran dalam rangka meningkatkan motivasi dan kepuasan kerja yang mengarah pada peningkatan kinerja karyawan Perusahaan Dazzle Yogyakarta.

1) Bagi Manajemen

Motivasi ditingkatkan dengan cara meningkatkan efektifitas peran pimpinan dalan memberikan arahan, bimbingan, petunjuk serta evaluasi berkenaan dengan pelaksanaan tugas dan pekerjaan. Kepuasan kerja lebih ditingkatkan dengan adanya pemberian bonus agar dapat memacu semangat kinerja setiap karyawan di Perusahaan Dazzle Yogyakarta. 2) Bagi Peneliti Selanjutnya

Penelitian selanjunya diharapkan tidak mengunakan variabel motivasi dan kepuasan kerja, namun memilih variabel lain untuk bahan penelitiannya yang dapat mempengaruhi kinerja karyawan.

\section{DAFTAR PUSTAKA}

Afandi, Pandi. (2018). Manajemen Sumber Daya Manusia Teori: Konsep dan Indikator. Pekanbaru: Zanafa.

As'ad, M. (2002). Psikologi Industri (Seri Ilmu Sumber Daya Manusia), Cetakan Keempat, Edisi Revisi. Yogyakarta: Penerbit Liberty.

Assagaf, Shannon Cecilia dan Lucky O.H. Dotulong. (2015). Pengaruh Disiplin, Motivasi dan Semangat Kerja terhadap Produktivitas Kerja Pegawai Dinas Pendapatan Daerah Kota Manado. Jurnal EMBA. Vol.3 No.2, Hal. 639-649.

Elida Prayitno. (1989). Motivasi dalam Belajar dan Berprestasi. Jakarta: Departemen Pendidikan dan Kebudayaan, Direktorat Jenderal Pendidikan Tinggi.

Ghazali, Imam. (2016). Aplikasi analisis multivariate dengan program IBM SPSS 23. Semarang: BPFE Universitas Diponegoro.

Gomes, Faustino Cardoso. (2003). Manajemen Sumber Daya Manusia. Jakarta: Andi Offset.

Gunarsa, Singgih D. (2008). Psikologi Anak: Psikologi Perkembangan Anak dan Remaja. Jakarta: PT BPK Gunung Mulia.

Handoko, T. Hani. (2011). Manajemen Personalia dan Sumberdaya Manusia. Yogyakarta: Penerbit BPFE.

Handoko, T. Hani. (2000). Manajemen, Edisi Kedua. Yogyakarta: Penerbit BPFE.

Handoko, T. Hani. (2002). Manajemen Personalia dan Sumberdaya Manusia. Yogyakarta: Penerbit BPFE.

Hasibuan, Malayu. (2008). Manajemen Dasar, Pengertian, dan Masalah. Jakarta: PT Bumi Aksara.

Kasmir, Kasmir. (2016). Manajemen Sumber Daya Manusia (Teori dan Praktik)-Cetakan Kesatu. Jakarta: Raja Grafindo Persada.

Moeheriono. (2012). Pengukuran Kinerja Berbasis Kompetensi. Jakarta: Raja Grafindo Persada. 
Nuraini, T. (2013). Manajemen Sumber Daya Manusia. Pekanbaru: Yayasan Aini Syam.

Panggalih, B., \& Zulaicha, R. (2012). Pengaruh Kepuasan Kerja terhadap Organization Citizenship Behavior Dengan Motivasi Kerja Sebagai Variabel Intervening pada Karyawan PT Telkom Tegal. Performance: Jurnal Personalia, Financial, Operasional, Marketing Dan Sistem Informasi, 16(2), 1-15. Retrieved from http://jos.unsoed.ac.id/index.php/performance/article/view/739

Prabowo, T. S., Noermijati, N., \& Irawanto, D. W. (2018). The Influence Of Transformational Leadership And Work Motivation On Employee Performance Mediated By Job Satisfaction. Jurnal Aplikasi Manajemen, 16(1), 171-178. https://doi.org/10.21776/ub.jam.2018.016.01.20

Saputra, A. R., \& Parwoto, P. (2020). Pengaruh Motivasi Dan Kepuasan Kerja Terhadap Kinerja Karyawan Pt. Karangmas Unggul Bekasi. Nidhomul Haq: Jurnal Manajemen Pendidikan Islam, 5(2), 211-226. https://doi.org/10.31538/ndh.v5i2.617

Sugiyono. (2013). Metode Penelitian Kuantitatif Kualitatif dan R\&D. Bandung: Alfabeta. Yuwono, I dkk. (2005). Psikologi Industri dan Organisasi. Surabaya: Fakultas Psikologi Universitas Erlangga. 